\title{
Productive performance of Nile tilapia (Oreochromis niloticus) fed at different frequencies and periods with automatic dispenser
}

\author{
[Desempenho produtivo de tilápias do Nilo (Oreochromis niloticus) alimentadas em diferentes \\ frequências e períodos com dispensador automático] \\ R.M.R. Sousa ${ }^{1}$, C.A. Agostinho ${ }^{2}$, F.A. Oliveira $^{1}$, D. Argentim ${ }^{1}$, P.K. Novelli ${ }^{1}$, S.M.M. Agostinho ${ }^{3}$ \\ ${ }^{1}$ Programa de pós-graduação - Universidade Estadual Paulista - FMVZ-UNESP - Botucatu, SP \\ ${ }^{2}$ Universidade Estadual Paulista - FMVZ-UNESP - Botucatu, SP \\ ${ }^{3}$ Cuesta Aquicultura - Botucatu, SP
}

\begin{abstract}
The performance of Nile tilapia (Oreochromis niloticus) raised in cages furnished with an automatic dispenser, supplied at different frequencies (once per hour and once every two hours) and periods (daytime, nighttime and both) was evaluated. Eighteen $1.0 \mathrm{~m}^{3}$ cages were placed into a $2000 \mathrm{~m}^{2}$ pond, two meters deep with a 5\% water exchange. One hundred and seventy tilapias, with initial weight of $16.0 \pm 4.9 \mathrm{~g}$, were dispersed into each $1 \mathrm{~m}^{3}$ cage and the feed ration was adjusted every 21 days with biometry. Data was collected from March to July (autumn and winter). Significant difference to final weight $(\mathrm{P}<0.05)$ among treatments was observed. The increase in feeding frequency improves the productive performance of Nile tilapias in cages and permitted better management of the food. The better feed conversion rate for high feeding frequency $\left(24\right.$ times day $\left.{ }^{-1}\right)$ can result in saving up to $360 \mathrm{~kg}$ of food for each ton of fish produced, increasing the economic sustenance for tilapia culture and suggesting less environmental pollution.
\end{abstract}

Keywords: fish, automatic feeding, cage, feed management

\section{RESUMO}

Avaliou-se o desempenho de tilápias-do-nilo (Oreochromis niloticus) produzidas em tanque-rede, providas de dispensadores automáticos de ração, alimentadas em diferentes frequências - uma vez por hora e a cada duas horas - e períodos - durante o dia, à noite ou ambos. Dezoito tanques-rede de $1.0 m^{3}$ foram colocados em um tanque de $2000 \mathrm{~m}^{2} \mathrm{com}$ dois metros de profundidade e renovação de água de $5 \%$. Cento e setenta tilápias, com peso inicial de $16.0 \pm 4.9 \mathrm{~g}$ foram distribuídas em cada tanque-rede de $1 \mathrm{~m}^{3}$ e a taxa alimentar foi ajustada a cada 21 dias junto com as biometrias. As medidas foram coletadas de março a julho (outono e inverno). Observou-se diferença significativa para peso final $(P<0.05)$ entre os tratamentos. $O$ aumento da frequência alimentar melhorou o desempenho produtivo de tilápias-do-nilo produzidas em tanque-rede e permitiu melhor manejo alimentar. A melhor conversão alimentar para alta frequência, 24 vezes dia ${ }^{-1}$, pode resultar em uma economia de até $360 \mathrm{~kg}$ de ração por tonelada de peixe produzido, melhorando a sustentabilidade econômica para produção de tilápia e sugerindo menor poluição ambiental.

Palavras-chave: peixe, alimentação automática, tanque-rede, manejo alimentar

\section{INTRODUCTION}

Manual feeding is the most used method in fish farming. However, the larger the production unit the more complex and onerous feed management becomes, due to the greater number of qualified people needed to detect changes in fish behavior and supply adequate ration.

Recebido em 18 de outubro de 2010

Aceito em 5 de outubro de 2010

E-mail: morgado7@yahoo.com.br 
The automatic fish feeders found on the market are manufactured with a device for launching the food long distances in the pond. These devices increase the cost of feeding and their use is too expensive for cages, where a feeder is necessary for each unit. However, there is an automatic feeder proposed by Agostinho et al. (2004) that is ideal for cages and costs four to five times less than the dispensers found in the market. This equipment consists of a container dimensioned according to the size of the cage, which releases the food in programmed periods and quantities.

The correct feed management is essential for improving fish growth and homogeny without compromising health, since food in excess builds metabolic alterations, in addition to water quality deterioration. For filter fish species that naturally feed at a high frequency, small ratio portions with a greater daily frequency is recommended (Meer et al., 1997). Yao et al. (1994), analyzing the effects of feeding frequency in Plecoglossus altivelis $(a y u)$, reported that the fish fed four times a day presented a lower triglyceride level than those fed only twice daily.

Nutrient assimilation by tilapia is affected by the interaction between diet protein level or free amino acids and the frequency in which the animals are fed. The free amino acids are absorbed faster than the amino acids present in the protein that needs intestinal proteases to convert them into di or tripeptides to be absorbed by enterocytes. Only after this absorption are they broken into amino acids by specific di or tripeptidases, for subsequent transport to the liver and to the target tissues. This process is slow and most of the free amino acids upon arrival at the target tissues are not used for protein synthesis anymore. The increase in feeding frequency efficiently supplies free amino acids while there are still amino acids from the prior feeding of protein diet (Lara, 2006).

Three systems are normally used to supply ration in tilapia farming and fishes in general: manual feeding, by demand and automatic. Automatic feeding - frequency of 12 times per day - for Nile tilapias this has presented superior results compared to other methods (Novato, 2000). Similar results were found for Dicentrarchus labrax (Azzaydi et al., 2000).
Trials with tilapias (Oreochromis niloticus), rainbow trout (Oncorhynchus mykiss), channel catfish (Ictalurus punctatus) and African catfish (Clarias gariepinus) showed that these species also feed at night. However, this practice cannot be done in commercial fish farming, due to the high cost of manual labor. The use of the automatic feeder would permit an increase in feeding frequency and food supply at night.

The feeding activity of tilapias is strongly linked to photoperiod, presenting greater activity at dawn and sunset (Toguyeni et al., 1997). Baras et al. (1995), studying juvenile of Nile Tilapia obtained a higher growth rate and better feed conversion for the nocturnal period than for fish fed during the day.

Some authors observed that some species such as rainbow trout, fed with auto-feeders, show feed peaks at dawn and at nightfall (Boujard and Leatherland, 1992; Shima et al., 2003). Yamamoto et al. (2002) observed 7 to $9 \%$ activity in the first hours of night with demand feeders for this same species and, when submitted to automatic feeding, the fish ingested a superior quantity of food compared to selffeeding. The ingestion peaks for this species are from 5-6 A.M. and 6-7 P.M. (Valente et al., 2001).

The efficiency of nocturnal feeding for fingerlings of African catfish was reported by Hossain et al. (2001). When fed at night (four times per night) with automatic feeders, they show better food conversion rate than those fed only during the day or during the day and at night. Thus, the present study had the objective of evaluating the performance of tilapia raised in cages, provided with automatic feeder, fed in different frequencies and periods.

\section{MATERIAL AND METHODS}

The experiment was carried out during autumn and winter in Brazil, from March, $17^{\text {th }}$ to July, $21^{\text {st }}$ (126 days). Eighteen $1.0 \mathrm{~m}^{3}$ cages arranged in line were placed in a $2000 \mathrm{~m}^{2}$ pond two meters deep with water renovation of 5 to $10 \%$. The tilapias were acquired from a commercial fish farm. The initial density was 170 fishes $/ \mathrm{m}^{3}$ with initial weight of $16.0 \pm 4.9$ grams. The daily feed ration was based on live weight (from $7 \%$ initial to $2 \%$ at the end). The quantity of food was 
adjusted every 21 days, when the size and weight measurements were taken. The commercial rations offered, according to the manufacturer, were prepared with $32 \%$ protein, $10 \%$ moisture, $3 \%$ fat, $5 \%$ fiber, $8 \%$ mineral, $1.8 \%$ calcium and $0.8 \%$ phosphorus. The food offering for each treatment is shown in Table 1.

Table 1. Scheme of food offering by automatic feeder

\begin{tabular}{lc}
\hline Period* & Frequency \\
\hline Day & \\
Night & once every two hours \\
Day and night & \\
\hline Night & \\
Day & once per hour \\
Day and night & \\
\hline
\end{tabular}

(*) Day $=$ from 6 am to $6 \mathrm{pm}$; Night $=$ from $6 \mathrm{pm}$ to 6am.

In order to reach the feeding frequency proposed, an automatic feeder was installed in each cage. The automatic feeder consists of a conic reservoir manufactured with impermeable material (glass fiber) containing an electromechanical mechanism that releases ration in pre-established intervals with a timer. The feed is dispensed into the interior of cages. Each automatic feeder holds four kilograms of food supplied twice a week.

Fish biomass was estimated in a 21-day interval in order to accurate the food rate to be offered. Biometry consisted of 20-fish weight samples from each experimental unit; this fairly high significance level was used to reduce the number of stressed fishes related to the frequent samplings.

The sampling began with the removal of ration from the automatic feeders to calculate the food intake during 21 days. The fish from the samples were weighed individually on an Instruthermbrand digital balance with $0.1 \mathrm{~g}$ precision, and after weighing the tilapias were returned to their respective cages. The mean weight of each treatment was calculated to adjust the feed rate offered based on commercial tables for fish farmers reducing rate for heavier fishes when temperature is lower than $19^{\circ} \mathrm{C}$ (May $20^{\text {th }}$ to July $21^{\mathrm{st}}$ ), Based on that, feed rate varied from $7.0 \%$ at the beginning to $2.0 \%$ at the end of the experiment. Animals were weighed six times during the experiment and all fish were weighed at the end of the period.

During the experiment, limnological variables were determined [transparency (Secchi disc); $\mathrm{pH}$ (Oakton peagometer), temperature and dissolved oxygen DO (YSI 55)]. They were monitored daily in the morning, at three distinct points in the pond, according to the position of the in flowing water. In the first 21 days the pond was supplied with spring water, due to low initial outflow, providing a volume renovation rate of only $5 \%$. After the first sampling, a new source of spring water was exploited to supply the pond, elevating the daily flow to $10 \%$.

The experiment was designed in a $2 \times 3$ factorial arrangement, in a total of six treatments with three replications. Data was compared using ANOVA with a model that considers the effect of feeding frequency, feeding period and the interaction between feeding frequency and feeding period. Duncan test at $5 \%$ probability level was used to compare the means.

\section{RESULTS}

The water temperature decreased from the beginning to the end of the experiment. Irregular variation in oxygen level in each pond was observed. Water transparency slightly decreased during the experimental progress and $\mathrm{pH}$ values demonstrated little variation from the beginning to the end of the experiment, assuming a tendency to alkalinity (Table 2).

The tilapias raised in cages fed at different frequencies and periods showed statistical difference $(\mathrm{P}<0.05)$ in performance evaluation. Table 3 presents final weights and feed conversion rates for the interaction between frequencies and periods. Despite the observation of an apparent relative difference in values between treatments, the feed conversion rates did not present statistical difference; the $F$ value was too high for this variable in ANOVA test. During the first week of the experiment there was a $5 \%$ loss of juveniles, but this mortality was probably due to transportation stress, fish adaptation to the cages and difference in water quality, since the survival for the remaining period was $100 \%$. 
Table 2. Average water temperature, dissolved oxygen, transparency and $\mathrm{pH}$ through the experiment with tilapia Juveniles

\begin{tabular}{|c|c|c|c|c|c|}
\hline Period & $\begin{array}{l}\text { Maximum } \\
\text { temperature } \\
\left({ }^{\circ} \mathrm{C}\right)\end{array}$ & $\begin{array}{c}\text { Minimum } \\
\text { temperature }\left({ }^{\circ} \mathrm{C}\right)\end{array}$ & $\begin{array}{c}\mathrm{DO} \\
(\mathrm{mg} / \mathrm{L})\end{array}$ & $\begin{array}{c}\text { Transparency } \\
\text { (cm) }\end{array}$ & $\mathrm{pH}$ \\
\hline $\operatorname{Mar} 17^{\text {th }}-\operatorname{Apr} 7^{\text {th }}$ & 28.6 & 23.7 & 3.2 & 49.5 & 7.9 \\
\hline Apr $8^{\text {th }}-$ Apr $27^{\text {th }}$ & 25.4 & 20.2 & 5.8 & 48.0 & 8.0 \\
\hline Apr $28^{\text {th }}-$ May $19^{\text {th }}$ & 23.4 & 20.3 & 6.1 & 45.0 & 7.8 \\
\hline May $20^{\text {th }}-$ Jun $9^{\text {th }}$ & 22.2 & 19.0 & 4.5 & 43.3 & 7.8 \\
\hline Jun $10^{\text {th }}-$ Jun $30^{\text {th }}$ & 22.3 & 18.4 & 5.8 & 35.8 & 8.1 \\
\hline Jul $1^{\text {st }}-\mathrm{Jul} 21^{\text {st }}$ & 23.5 & 17.7 & 4.7 & 40.5 & 7.9 \\
\hline
\end{tabular}

Table 3. Productive performance of tilapia juveniles during autumn and winter

\begin{tabular}{llll}
\hline \multicolumn{3}{l}{ Feeding frequency } & \multicolumn{3}{c}{ Final weight $(\mathrm{g})$} \\
\hline & day & night & day and night \\
once per hour & $264.9 \pm 71.4 \mathrm{ABa}$ & $245.3 \pm 66.0 \mathrm{Ba}$ & $285.8 \pm 67.1 \mathrm{Aa}$ \\
once every two hours & $264.4 \pm 54.2 \mathrm{Aa}$ & $229.7 \pm 57.9 \mathrm{Ba}$ & $242.1 \pm 59.4 \mathrm{ABb}$ \\
& \multicolumn{2}{c}{ Feed conversion rate } \\
once per hour & $1.09 \pm 0.48$ & $1.17 \pm 0.53$ & $1.04 \pm 0.21$ \\
once every two hours & $1.15 \pm 0.34$ & $1.65 \pm 0.63$ & $1.15 \pm 0.45$ \\
\hline
\end{tabular}

Means within a row with no common capital letter or within a column with no common lower-case letter differ (Duncan test, $\mathrm{P}<0.05$ ).

\section{DISCUSSION}

As shown in Table 2 it is verified that dissolved oxygen levels in the pond found during the experiment were below the levels observed by Paes (2006), who found values of $8 \mathrm{mg} / \mathrm{L}$ of dissolved oxygen in the water in Nova Avanhandava lake, where tilapias are raised in cages. According to Boyd and Tucker (1998) large periodic fluctuations in dissolved oxygen may reduce fish performance.

The $\mathrm{pH}$ values showed little variation from the beginning to the end of the experiment, assuming a tendency toward alkalinity near to 7.8 at the beginning of the experiment and 8.1 at its conclusion. Water transparency decreased slightly during the course of the experiment, with an average of $45.0 \mathrm{~cm}$. This reduction may have occurred due to phytoplankton blooming (Sipaúba-Tavares, 1995).

The weight gain results can be promising since the experiment was conducted in autumn and winter. The mean temperature shown in Table 2 was below the ideal temperature for this species that, according to Kubtiza (2000), can range between 27 and $32^{\circ} \mathrm{C}$.

It should be emphasized that the feed conversion rate for low feeding frequency (once every two hours) was 1.40 and for high feeding frequency (once per hour) was 1.04 (Table 3), which can result in saving $360 \mathrm{~kg}$ of food for each ton of fish produced, increasing the economic sustenance for tilapia culture, additionally suggesting less environmental pollution.

In the present study there was interaction between feeding frequency and period. For the feeding frequency of once per hour and once every two hours there was no significant difference on final weight of tilapias fed during the day period and the ones fed during day and night (Table 3). For the once per hour feeding frequency the performance of tilapias fed during the day-night period was higher than tilapias fed only at night $(\mathrm{P}<0.05)$. For the once every two hours feeding frequency, the best performance was for tilapias fed during the day. The lower level of dissolved oxygen in water at night may have contributed to the inversion of better productive performances related to feeding frequency, since during feeding tilapias double their oxygen consumption.

Correlated to feeding periods, the only significant difference for feeding frequency occurred in the day/night period, in which the once per hour frequency was superior to that of once every two hours for final weight $(\mathrm{P}<0.05)$. This tendency matches the results obtained by 
several authors for different species (Tung and Shiau, 1991; Koskela et al., 1997; Novato, 2000; Padua et al., 2001).

One common practice in commercial tilapia farming is a periodic classification to reduce the lack of uniformity among the fish in cages, which causes stress that generally results in mortality after handling. The results obtained during this experiment demonstrated greater uniformity in the treatment with a higher feeding frequency, confirming the results obtained by Koskela et al. (1997) for the species Coreogonus lavaretus and by Wang et al. (1998) for a hybrid sunfish.

The data presented indicate that the increase in feeding frequency associated with daytime or day/night time feeding improved the performance of Nile Tilapia in cages, suggesting that a greater number of feeding permits better exploitation of feed and availability of dissolved oxygen. Additional studies should be conducted to better define feeding frequencies and periods for other species growth in national and global aquiculture, at the same time contributing for the sustenance of the activity.

With the use of automatic feeders it was possible to supply the food in small portions improving the feed exploitation and reducing waste and competition for food. According to Tsadik and Kutty (1987), food consumption and absorption by tilapias and their growth are influenced by the quantity of oxygen dissolved in the water.

When feed is offered in higher frequencies the daily demand for oxygen is lessened. Furthermore, species such as tilapia, which possess a long digestive tract and omnivorous feeding habits, can take better advantage of the food nutrients when the feeding frequency is higher at the right time of the day, resulting in increased weight gain. Thus, a greater parceling of daily ration quantity is recommended for feed management for tilapias fed during the day or day/night.

The fish performance from the nocturnal feeding period treatment, done with an automatic feeder, was significantly less than the other treatment performance $(\mathrm{P}<0.05)$, in contrast to the data obtained by Baras et al. (1995) with juvenile of Nile Tilapia and by Kerduchuen and Legendre
(1991), for Heterobranchus longifilis. However, the performance of tilapias fed only at night presented results which suggested that tilapias also feed at night. This feeding habit was also observed for the rainbow trout by diverse authors (Boujard and Leatherland, 1992; Valente et al., 2001; Shima et al., 2003; Yamamoto et al., 2002).

In the present study it can be observed that tilapias presented good exploitation of the food in all periods evaluated, with better results for high frequencies during day and night periods. Nevertheless, nocturnal feeding is not practiced currently in Brazil due to lack of studies, information and cost of manual labor.

\section{CONCLUSIONS}

The increase in feeding frequency improves the performance of Nile tilapia in cages and the greater number of feedings allows better food exploitation by the fish. It is suggested that during autumn and winter, to produce tilapia in the phases from 16.0 to $250.0 \mathrm{~g}$, ration should be supplied only during the day, turning off the feeders at night.

\section{REFERENCES}

AGOSTINHO, C.A.; LIMA, S.L.; FORTES, J.V. et al. Automatic ration dispenser. Patente de Invento n. 0403612-3, 23 de agosto de 2004.

AZZAYDI, M.; MARTÍNEZ, F.J.; ZAMORA, S. et al. The influence of nocturnal vs. diurnal feeding under winter conditions on growth and fed conversion of European sea bass (Dicentrarchus labrax, L.). Aquaculture, v.182, p.329-338, 2000.

BARAS, E.; THOREAU, X.; MELARD. Influence of feeding time on growth and feed conversion rates in juvenile tilapia (Oreochromis niloticus). Cah. Etholfoldam Appl. Hum., v.15, p.71-80, 1995.

BOUJARD, T.; LEATHERLAND, J.F. Demandfeeding behavior and dial pattern of feeding activity in Oncorhynchus mykiss held under different photoperiod regimes. J. Fish Biol., v.40, p.535-544, 1992.

BOYD, C.E.; TUCKER, C.S. Pond aquaculture water quality management. Boston: Kluwer Academic Publishers, 1998. 700p. 
HOSSAIN, M.A.R.; HAYLOR, G.S.; BEVERIDGE, M.C.M. Effect of feeding time and frequency on the growth and feed utilization of African catfish Clarias gariepinus (Burchell 1822) fingerlings. Aquacult. Res., v.32, p.999-1004, 2001.

KERDCHUEN N.; LEGENDRE M. Influence de la frequence et de la periode de nourrissage sur la croissance et l'efficacite alimentaire d'un silure africain, Heterobrabcus longilis. Aquat. Living Res., v.4, p.241-248, 1991.

KOSKELA, J.; JOBLING, M.; PIRHONEN, J. Influence of the length of the daily feeding period on feed intake and growth of whitefish, Coregonus Lavar. Aquaculture, v.156, p.35-44, 1997.

KUBITZA, F. Tilápia, tecnologia e planejamento na produção comercial. Jundiaí: USP, 2000. $285 \mathrm{p}$.

LARA, L.B. Segurança alimentar na produção de organismos aquáticos. In: FEED \& FOOD, SEGURANÇA ALIMENTAR PARA A SAÚDE E BEM-ESTAR DO HOMEM. Porto Feliz: Curuca Editora, 2006. p.19-20.

MEER, M.B.V.; HERWAARDEN, H.; VERDEGEM, M.C.J. Effect of number of meals and frequency of feeding on voluntary feed intake of Colossoma macropomum (Cuvier). Aquacult. Res., v.28, p.419-432, 1997.

NOVATO, P.F.C. Comparação entre os sistemas de alimentação de demanda, manual $e$ automática sobre a performance da Tilápia Vermelha (Oreochromis spp). 2000. 87f. Dissertação (Mestrado em Aquicultura) - Centro de Aquicultura, Universidade Estadual Paulista, Jaboticabal, SP.

PADUA, D.M.C. A frequência alimentar e a utilização dos nutrientes da dieta pela Tilápia do Nilo, Oreochromis niloticus. 2001. 103f. Tese (Doutorado em Zootecnia) - Centro de Aquicultura, Universidade Estadual Paulista, Jaboticabal, SP.

PAES, J.V.K. A ictiofauna associada e as condições limnológicas num sistema de piscicultura em tanques-rede, no reservatório de Nova Avanhandava, baixo rio Tietê (SP). 2006. 177f. Dissertação (Mestrado em Biologia) Instituto de Biociências, UNESP, Botucatu, SP.
SHIMA, T.; YAMAMOTO, T.; FURUITA, H. et al. Effect of the response interval of self-feeders on the self-regulation of feed demand by rainbow trout (Oncorhynchus mykiss) fry. Aquaculture, v.224, p.181-191, 2003.

SIPAÚBA-TAVARES, L.H. Limnologia aplicada à aquicultura. Jaboticabal: UNESP, 1995. 72p. (Boletim técnico).

TOGUYENI, A.; FAUCONNEAU, B.; BOUJARD, T. Feeding behavior and food utilization in tilapia, Oreochromis niloticus: Effect of sex ratio and relationship with the endocrine status. Physiology and Behavior, v.62, p.273-279, 1997.

TSADIK, G.G.; KUTTY, M.N. Influence of ambient oxygen on feeding and growth of the tilapia, Oreochromis niloticus (Linnaeus) ARAC/87/WP/10. Nigeria: Port Harcourt, 1987. $16 \mathrm{p}$.

TUNG, P.H.; SHIAU, S.Y. Effects of meal frequency on growth performance of hybrid tilapia, Oreochromis niloricus x 0 . aweus fed different carbohydrate diets. Aquaculture, v.92, p.343-350, 1991.

VALENTE, L.M.P.; FAUCONNEAU, B.; GOMES, E.F.S. Feed intake and growth of fast and slow growing strains of rainbow trout (Oncorhynchus mykiss) fed by automatic feeders or by self-feeders. Aquaculture, v.195, p.121131, 2001.

WANG, N.; HAYAWARD, R.S.; NOLTIE, D.B. Effect of feeding frequency on food consumption, growth, size variation, and feeding pattern of age-0 hybrid sunfish. Aquaculture, v.165, p.261-267, 1998.

YAMAMOTO, T.; SHIMA, T.; FURUITA, H. Influence of feeding diets with and without fish meal by hand and by self-feeders on feed intake, growth and nutrient utilization of juvenile rainbow trout (Oncorhynchus mykiss). Aquaculture, v.214, p.289-305, 2002.

YAO, S.J.; UMINO, T.; NAKAGAWA, H. Effect of feeding frequency on lipid accumulation in ayu. Fish Sci., v.60, p.667-671, 1994. 